

\title{
Clonación de la lengua y elogio de la lectura
}

\author{
Mercedes Falconi
}

A quién clonaría, uno, dos, tres...

U na importante revista cultural del país aborda a varios personajes nacionales, todos famosos y respetados, con una pregunta inesperada, a quemarropa: ¿a quién clonaría usted y por qué lo haría?

El resultado de la encuesta es homogéneo. Cada uno de los entrevistados, a su aire y como si fuese una especie de dios moderno, fatigado y apresurado en el sexto día de la Creación, se pronuncia abiertamente: uno afirma que a su novia; otro, cándido, que a la madre Teresa; otro, político y pacifista, se inclina por Gandhi; otro, por fin, nombra a Rimbaud; varios no pueden contenerse: le clonaría al Papa de Roma. En tiempos de eufemismos, los argumentos se repiten. Todos aman el consenso y la paz. Todos buscan la felicidad personal y del mundo. Todos se inclinan ante la verdad y la belleza...

\section{El detector de mentiras}

Después de leer la revista con un cierto detenimiento, yo misma me sometí al test o juego de a quién clonaría, uno, dos, tres... La prueba no es fácil. El corazón opina y convierte. La cabeza medita y advierte: recuerda y proyecta.

\footnotetext{
* Escritora
} 
Para minimizar los riesgos, me sometí al detector de mentiras que llevo siempre conmigo: la conciencia ciudadana. Empecé, pues, por apuntar y registrar el santo y la seña de las personas a quienes yo NO clonaría jamás, bajo ningún concepto.

Influida por el filósofo argentino Mario Bunge, tan admirado por mí, descubrí algo que siempre había sabido: yo no clonaría jamás a sacerdotes ni a redentores, a militares ni a policías. Esos sujetos del orden que nos escamotean la libertad y su sentido.

(Debo confesar que nunca me he llevado bien con los guardianes del cielo y de la tierra).

La luz contra las tinieblas, yo pregunto: ¿quién le podría clonar al inventor de la "guerra preventiva"? ¿Quién podría fotocopiar a uno de sus acólitos? Es evidente que le han robado a nuestro humilde planeta, el concepto de fraternidad y el sentimiento de solidaridad.

No es demagogia ni soberbia pero tampoco le clonaría, en tanto lectora, al promotor o inventor del teléfono móvil: ese aparato tiránico que nos inmoviliza en cualquier sitio. Todos sabemos aunque callamos, que el móvil o celular es útil, a menudo, para cortar o robar horas de conversación o lectura, o cine o escritura, o paisaje que se mira.

Bajo ningún concepto yo le clonaría, en tanto adversaria de la falsedad y la solemnidad, a ninguno de esos lectores de noticias que payasean supuestas novedades en la televisión. En defensa del buen humor y en abierta solidaridad con Mafaldita, a nadie en sus cabales se le podría ocurrir clonar la sopa.

Como la memoria es un tábano que aviva la imaginación, tampoco le clonaría a mi profesora de literatura que era una señora aburrida que pertenecía con ventaja y alevosía, sin rubores, al viejo club de esos caducos profesores de literatura que siguen quemando, día a día, la biblioteca de don Quijote de la Mancha, el mejor promotor de lectura de todos los tiempos. 
Esa profesora de literatura le robaba imaginación a la literatura, pues se sujetaba sin concesiones al programa oficial, funeral y nacional, como tantos otros profesores.

Cuando me disponía, por fin, a resolver el enigma y escribir el nombre de la persona uno, dos, tres... a quién yo clonaría, recibí la invitación para escribir este artículo que, casualmente, busca clonar la pasión de la lectura.

Se trata, desde luego, de una idea loca sobre la que voy ensayar unas breves opiniones.

\section{Clonar la pasión por la lectura}

¿Vale la pena intentar esta clonación? ¿O, como la oveja Dolly, la clonación está condenada al fracaso por un inevitable envejecimiento prematuro? ¿O, tal vez, carece de sentido en la era de la información buscar implantar la era de la reflexión?

Todo depende del punto de vista. Todo depende del enfoque que hagamos. Hay que clonar la pasión por la lectura para entender la vida. Hay que clonar esta pasión hasta convertir a la lectura en una actividad permanente, cotidiana, placentera, espontánea y necesaria, como es la alimentación o el juego.

La lectura no debe ser una forma de aprender, concepto que restringe su territorio, sino que debe ser una forma de vivir.

No se lee para aprender literatura ni para conocer a nuevos escritores: se lee para asombrarse ante la magia invisible de la vida. La lectura es parte de esa magia.

La lectura es un ejercicio de la inteligencia y de las emociones, de la cabeza y del corazón, también de todos los sentidos. La lectura empieza por el asombro y la emoción y concluye por el desarrollo intelectual.

La lectura, como una forma de vida, exige que se la practique en todo momento, vitalmente: en invierno y en 
verano, en temporada de clases y en temporada de vacaciones. En el día y en la noche.

Cuando se adquiere el hábito de la lectura se lee todo lo que se puede, en cualquier momento. Se lee por placer. Luego, poco a poco, la lectura se vuelve más rigurosa y selectiva.

Leer es una experiencia íntima y personal que no se pude comparar con jugar fútbol, salir al parque o ver televisión.

Creo en la lectura y en sus posibilidades de comunicación. Creo que una palabra despierta mil imágenes y promueve mil conceptos.

Entonces, la propuesta de clonar la pasión por la lectura, no solo es buena sino también necesaria. Urgente. Pero antes de entrar en el laboratorio de la clonación, es preciso analizar y precisar quiénes se oponen -contra viento y marea- a esta iniciativa.

\section{El historicismo contra la lectura}

Utilicemos el detector de mentiras. Creo, en primer lugar, que se opone el programa oficial y funeral que no busca acercar al niño/adolescente/joven a la lectura. El programa oficial y funeral busca algo más vistoso e inútil: busca contar la historia de la "literatura", palabra que en este caso hay que escribirla entre comillas. Busca, para más precisión, promover la PARALITERATURA: materia que se enseña a través de la historia, a través de la sociología, a través de la antropología.

\section{El didactismo contra la lectura}

Un segundo enemigo de la lectura es, desde luego, el didactismo: incapaz de generar amor, odio, sentido de aventura. Incapaz de apasionar a vida o muerte. 
El didactismo se hermana con el historicismo y no permite pensar en una clonación. Porque el didactismo, siempre pulcro y bien peinado para la foto oficial, recurre a la perspectiva metodológica e histórica... De esta forma obliga a memorizar el siglo, el año, la hora, el día y el segundo en que nació Cervantes, aunque nunca promueva su lectura. Este didactismo olvida que una obra tiene un útero social y personal pero que, en última instancia, transciende a su tiempo. Una ilustración demoledora. Una novela o una tragedia se inscribe -cronológicamente- en una época específica, pero se renueva -siempre- en cada lector y en cada tiempo. El célebre cuento Pierre Menard autor del Quijote, de Jorge Luis Borges, es una demostración estética e inapelable de esta afirmación. Nadie como Borges enseña que el tiempo del lector es, en cualquier época, el verdadero tiempo de una obra literaria.

Desde luego que entre el acto de "escribir" y el acto de "leer" se producen acontecimientos históricos, hechos políticos y sociales, análisis estilísticos, comentarios especializados o el inevitable descubrimiento de influencias. Esto es una opulencia o gula informativa, que ayuda a visualizar escenarios pero que no se inscribe en lo esencial.

Digámoslo de otra manera. La paradoja del didactismo en su versión suprema de paraliteratura, es terrible y deprimente. El didactismo paraliterario cuenta todo o casi todo sobre la vida de un autor, pero evita - de una u otra manera- que se lea su obra literaria en vivo, íntegramente. Evita así, lamentablemente, el necesario diálogo personal e íntimo entre el escritor y el lector.

De esta forma no se puede clonar la pasión por la lectura. Porque sucede lo contrario. Los estudiantes y aprendices empiezan, espantados y aburridos, no solo a detestar la asignatura/literatura sino también al profesor y a los autores consagrados y citados, clasificados y memorizados. Autores que más tarde y con razón, son puntualmente olvidados. 


\section{El menú único no forma el paladar}

El didactismo paraliterario es, en última instancia, algo tan noble como el triglicérido: algo que llena pero no alimenta. No forma el paladar. El menú único es el tercer enemigo de la lectura. Enemigo porque no contribuye a la creación de hábitos lectores ni al desarrollo de la competencia literaria que permite escoger, valorar y entender los textos.

La competencia para leer en un nivel más profundo y metafórico, se adquiere en la diversidad. O en el libro que se lee apasionadamente.

Pero, desde luego, si es que no se cultiva la competencia literaria, no hay cómo cultivar la pasión por la lectura.

$\mathrm{Ni}$ se cultiva la capacidad de elaborar textos propios con un mínimo nivel estilístico.

$\mathrm{Ni}$ se cultiva la capacidad de expresarse oralmente, con claridad. Una ilustración. Con motivo de la reciente Copa América de Fútbol, le oí a un narrador/periodista deportivo que decía:

-Ese futbolista, que corre por la media cancha, es una vergüenza: no SE ESFORZA. No siente la camiseta nacional.

El periodista seguramente no almuerza, SINO ALMORZA. Así es el uso estomacal del idioma. De esta forma no se escoge el lenguaje de la calle para comunicarse, sino, como decía el escritor español Fernando Lázaro Carreter, se escoge "el de la calle de la ignorancia".

\section{El didactismo que pregona a los clásicos y acaba con ellos}

Hay una metodología arqueológica con gran acogida en el programa oficial y funeral, que es un cuarto enemigo de la clonación que tenemos entre manos. Es la metodología 
que pregona que es necesario empezar por el principio: esto es, por los autores más antiguos y complejos. Esta metodología cita a Homero y Virgilio, desde luego. Cita a Sófocles y cita, en nuestra lengua, al Cantar del Mío Cid.

Utilicemos, una vez más, el detector de mentiras. Esta propuesta metodológica es traumática y debe ser revisada. Porque empezar con los clásicos implica, sencillamente, acabar con ellos. Implica acabar con la literatura y la lectura.

En una serie de diálogos vitales, profundos y eruditos, Jorge Luis Borges y Ernesto Sabato muestran sus poderosas simpatías y sus poderosas diferencias políticas, literarias y filosóficas, pero ambos escritores coinciden en algo que es ilustrativo: para que un lector joven le encuentre sentido y cercanía a la literatura, hay que empezar por lo nuevo y válido. No hay que empezar por los grandes clásicos, sino por lo autores contemporáneos.

\section{La lectura calificada no se puede clonar}

La calificación de la lectura literaria es un quinto y peligroso enemigo de la pasión por el libro y la narración que nos narra. A la lectura lúdica no hay forma de ponerle una nota. La lectura individual e íntima no admite una valoración a distancia, con los instrumentos de la educación formal. La lectura calificada y uniformada no se puede clonar.

El placer por la lectura no se puede medir matemáticamente. En la lectura como en la vida, es más viable una especie de focus group: esa modalidad valorativa que permite registrar emociones, tendencias, valores, aproximaciones, distancias, en fin.

\section{El mapa y la brújula}

No creo, por cierto, que todo deba quedar sujeto a la improvisación o inspiración del motivador o profesor. Creo, al 
contrario, que es necesario entender en qué consiste tener un mapa y una brújula, cuando queremos clonar la pasión por leer.

Un maestro no debe tener un mapa donde se anuncia y se muestra, en alarde pedagógico, dónde queda una montaña y dónde un río, dónde está un lago y dónde una cascada, dónde un mar abierto y dónde una playa risueña y acogedora. Un maestro debe tener una brújula que sirva de orientación y ofrezca pautas y rutas, pero que no suprima la experiencia personal, el riesgo y la aventura, el placer de la conquista o la sorpresa.

Hay mapa cuando el programa de literatura se convierte en una prioridad que debe cumplirse, registrarse y calificarse "objetivamente" en un año escolar.

Hay brújula cuando se motiva: cuando se manda a leer y se entiende que la calificación de esa lectura no se mide en notas, sino en vida, sentidos, desafíos. $O$, desde otro punto de vista, hay una mayor capacidad de comunicación. Precisemos. En América latina existe un déficit semántico que es realmente preocupante. El nivel, en ciertos casos, es de comics. Porque la juventud emplea entre setecientas y mil doscientas palabras para "expresarse" cotidianamente. Para chatear. Para dejar un "mensa en el celu"... Esto es terrible. Porque no se trata de un servicio de mensajes cortos, sino de una traición a nuestra lengua cuya riqueza sobrepasa las 70000 palabras. $O$, más bien, una traición a nuestras posibilidades expresivas.

\section{Los sustitutos del libro}

Un séptimo enemigo de nuestra anhelada clonación es el auge y la publicidad que se ha dado a los supuestos sustitutos definitivos del libro.

Acaba de realizarse en varios países de América latina una encuesta que anuncia, a quemarropa, que los niños, los jóvenes y los adultos se informan de la "realidad" a través de la televisión y de la Internet, de la prensa escrita y de la 
radio. Esto es positivo. Esto es un signo de la modernidad y de los tiempos que vivimos. Lo grave está en que, según el análisis de la misma encuesta, esa información no es debidamente asimilada y evaluada, si es que además no se recurre a la lectura de libros. Porque todo se vuelve epidérmico y efímero. Volátil.

En otras palabras, el informe de marras explica que es necesario leer para comprender más profundamente la realidad.

\section{Para clonar la pasión por la lectura hay, primero, que des-escolarizar la lectura}

Es preciso des-escolarizar la lectura para convertirla en algo cotidiano. Para convertirla en una fuente de recreación y de emoción. En un camino idóneo para divertirse intensa y fácilmente, solo o en grupo. Para convertirla en un modo válido para conocer otras realidades y otros mundos. En un espejo distinto donde uno puede verse desde todos los ángulos.

La lectura nos da una mirada más abierta sobre los hombres y sobre el mundo, y nos convoca a rechazar la realidad como un hecho irrevocable.

Leer también es un sentimiento y como tal es susceptible de generar amor y odio y por lo tanto no puede ser impuesto.

\section{Como el pasajero en el avión}

No hay populismo ni utopismo: para aprender literatura hay que leer libros de literatura, no reseñas o cronologías. Esto es un punto decisivo de nuestra reflexión. El rol del lector es introducirse directamente en el libro, como se introduce un pasajero en el avión, confiando en el piloto y en los radares de la aeronáutica, para llegar a otro sitio. A otra expe- 
riencia. A otra realidad. Para vivir la aventura a plenitud. Sin mediaciones. En función de todos los mundos posibles. En función de crear, también, la biblioteca personal.

\section{La biblioteca personal es como la otra ciudad donde se vive}

El maestro debe buscar que cada niño/adolescente/joven lector forme y conforme su biblioteca personal. Una biblioteca es una forma de empezar a clonar la pasión por la lectura con los libros.

Una biblioteca, más que un currículum de presentación, es el testimonio de una vida. De un pasado. De un sueño. Porque los libros no solo los leemos, sino que nos leen. No hablo de la biblioteca impecable, que ocupa o decora la pared, sino de la biblioteca con libros agitados, páginas transitadas o subrayadas, libros -en fin- con señales de vida. O con muestras de que son, en realidad, parte de la familia.

Nadie lee todos los libros que tiene en su biblioteca, pero quién no sueña en leerlos cuando los compra. Los libros sin leer están ahí, pacientes, esperando su turno, en nuestra biblioteca personal. El tiempo de cada libro, por cierto, obedece a una lógica desconocida, imprevisible.

Los libros son una patente de vida. Los libros son una patente de lectores. De allí la responsabilidad de un escritor al momento de escribir un libro, la responsabilidad del maestro cuando lo sugiere, también la del bibliotecario y la del librero.

Un libro infantil malo termina acabando, en el largo plazo, con el lector. En la novela "La sombra del viento", escrita por el español Carlos Ruiz Zafón, se afirma: "Pocas cosas marcan tanto a un lector como el primer libro que realmente se abre camino hasta su corazón. Aquellas pri- 
meras imágenes, el eco de esas palabras que creemos haber dejado atrás, nos acompañan toda la vida y esculpen un palacio en nuestra memoria al que, tarde o temprano, vamos a regresar". Esta novela que revaloriza la literatura, transcurre en un cementerio de libros olvidados.

La lectura no solo nos permite abrazar al autor, sino también abrazar la vida. El escritor mexicano Gabriel Zaid, muestra su cédula de identidad con estas palabras: "Quizá la medida de la lectura no debe ser el número de libros leídos, sino el estado en que nos dejan. ¿Qué demonios importa si uno es culto, está al día o ha leído todos los libros? Lo que importa es cómo se anda, cómo se ve, cómo se actúa después de leer. Si la calle y las nubes y la existencia de los otros tienen algo que decirnos. Si leer no hace, físicamente, más reales".

\section{Un pacto con el diablo}

Concluyo. Empecé escribiendo de la clonación y quiero terminar de la misma manera. En estos tiempos de fuego artificial, ¿a quién yo clonaría?

Recurro por última vez al detector de mentiras. En un hermoso relato de Ítalo Svevo, se cuenta la historia de un hombre que antes de acostarse se pregunta qué ocurriría si el diablo se presentara en su alcoba para proponerle el consabido pacto. El cansado protagonista está dispuesto a entregar su alma pero no sabe qué pedir a cambio...

En tanto la lectura es una aventura más endemoniada que angelical, yo le recomendaría al Diablo, a cambio de mi alma, un libro de Jorge Luis Borges. Luego, ya en plan de amigos, le clonaría y le pediría que se convierta en promotor de lectura, pues el Diablo sabe más de tentaciones que de prohibiciones. Sabe más de placeres y no de castigos.

No cabe duda. Hay que clonarle al Diablo. Para tentarle a la vida y eternizar la pasión por la lectura. 
